$$
\begin{aligned}
& \text { Loyola Law School Los Angeles } \\
& \text { Legal Studies Research Paper Series } \\
& \text { Paper No. 2011-10 } \\
& \text { and } \\
& \text { University of California, Irvine School of Law } \\
& \text { Legal Studies Research Paper Series } \\
& \text { Paper No. 2011-11 }
\end{aligned}
$$

\title{
The Supreme Court's Shrinking Election Law Docket, 2001-2010: A Legacy of Bush v. Gore or Fear of the Roberts Court?
}

\author{
Richard L. Hasen \\ Loyola Law School Los Angeles, \\ UC Irvine School of Law, Visiting
}

Paper can be downloaded free of charge from the

Social Science Research Network (SSRN). 


\section{THE SUPREME COURT'S SHRINKING ELECTION LAW DOCKET, 2001-2010: A LEGACY OF BUSH V. GORE OR FEAR OF THE ROBERTS COURT? RICHARD L. HASEN*}

\section{INTRODUCTION}

A funny thing happened after the Supreme Court decided Bush v. Gore, ${ }^{1}$ the controversial December 2000 case ending the presidential election litigation between Al Gore and George W. Bush: over the next decade, from 2001 to 2010, the number of election law cases decided by the Supreme Court with a written opinion fell to 30 cases, the lowest level since the 1950s. The drop occurred at the Supreme Court even as the amount of election litigation in the lower courts more than doubled compared to the period just before Bush v. Gore and even as the scholarly field of election law exploded.

This brief Article describes the drop in Supreme Court election law cases in the first decade of the twenty-first century, and offers at least a partial explanation as to the reasons for the drop. Although the general amount of election law litigation has risen dramatically since 2000, the number of cases in which parties sought Supreme Court review declined by more than 36 percent from the 1991-2000 decade compared to the 2001-2010 decade. The decline appears particularly steep after Justice O'Connor left the Court, replaced by Justice Alito.

Factoring that decline into account, the data show that the Court issued written opinions in nearly the same percentage of election law cases each decade in which parties sought Supreme Court review-11.9\% of cases in the 1991-2000 decade, and $10.5 \%$ of cases in 2001-2010. While I cannot exclude the possibility that the Court shied away from hearing some election law cases out of Bush v. Gore fatigue or as the result of random noise, the drop in the number of election law cases in which litigants sought Supreme Court review cases seems to explain a great deal of the decline.

This Article concludes by considering why the number of cases in which litigants sought Supreme Court review dropped so precipitously in 2001-2010 even as the total number of election law cases in the lower courts increased

\footnotetext{
* Visiting Professor of Law, UC Irvine School of Law; William H. Hannon Distinguished Professor of Law, Loyola Law School, Los Angeles. Thanks to Michael Solimine and Justin Levitt for very helpful suggestions and to Jason Campbell, Denny Chan, Joy Shoemaker, and Christina Tsou for excellent research and library assistance.

${ }^{1} 531$ U.S. 98 (2000).
} 
dramatically. One reason is that liberal litigants who had sought review especially in voting rights cases in the 1990-2000 period were less willing to do so in the 2001-2010 period, likely because they expected unfavorable results before the more conservative Roberts Court. The $2005-2010$ period is especially important; the number of election law petitions in the Supreme Court dropped precipitously after Justice Alito joined the Court. The other reason is that many of the lower court cases making up the election law explosion were state cases involving state statutory interpretation issues, rarely raising federal constitutional or statutory claims within the Supreme Court's purview.

\section{THE NUMBERS}

Elsewhere I have chronicled the tremendous jump in twentieth century election law litigation which accompanied the Supreme Court's decision to enter into the "political thicket" of reapportionment beginning with the Court's 1962 decision in Baker v. Carr. $^{2}$ From the period 1901-1960, the Supreme Court decided an average of 10 election law cases per decade. In contrast, from 19612000, the Court averaged 60 cases per decade, a six-fold increase. ${ }^{3}$ From 19912000 specifically, the Court decided 54 election law cases. ${ }^{4}$

Measured as a percentage of election law cases on the Supreme Court's total docket, in the 1901-1960 period, election law cases made up a meager $0.7 \%$ of the Court's cases decided with a written opinion. From 1961-2000, that percentage increased seven and one-half times to an average 5.3\% of cases. ${ }^{5}$ From 1991-2000 specifically, election law decisions made up $6.3 \%$ of the Court's docket. ${ }^{6}$

The 1991-2000 decade ended with the Supreme Court's most controversial election law opinion of at least a generation, the Bush v. Gore decision. How did the Court's election law docket fare in the 2001-2010 period right after Bush v. Gore? From 2001-2010, the Supreme Court decided 30 election law cases with a written opinion, half the average for the 1961-2000 period. The 2001-2010

\footnotetext{
2369 U.S. 186 (1962).

${ }^{3}$ Richard L. HASEN, THE SUPREME COURT AND ELECTION LAW: JUdGING EQUALITY FROM BAKER V. CARR TO BUSH V. GORE 1-3 (2003).

${ }^{4} I d$., Appendix II.

${ }^{5} \mathrm{Id}$.

${ }^{6}$ The Court wrote 54 election law cases out of 852 total cases with a written opinion in the 1991 2000 period.
} 
election law cases made up $4.2 \%$ of the Court's docket for the decade. ${ }^{7}$ Figures 1 and 2 show the most recent decade's data in comparison to the older decades.

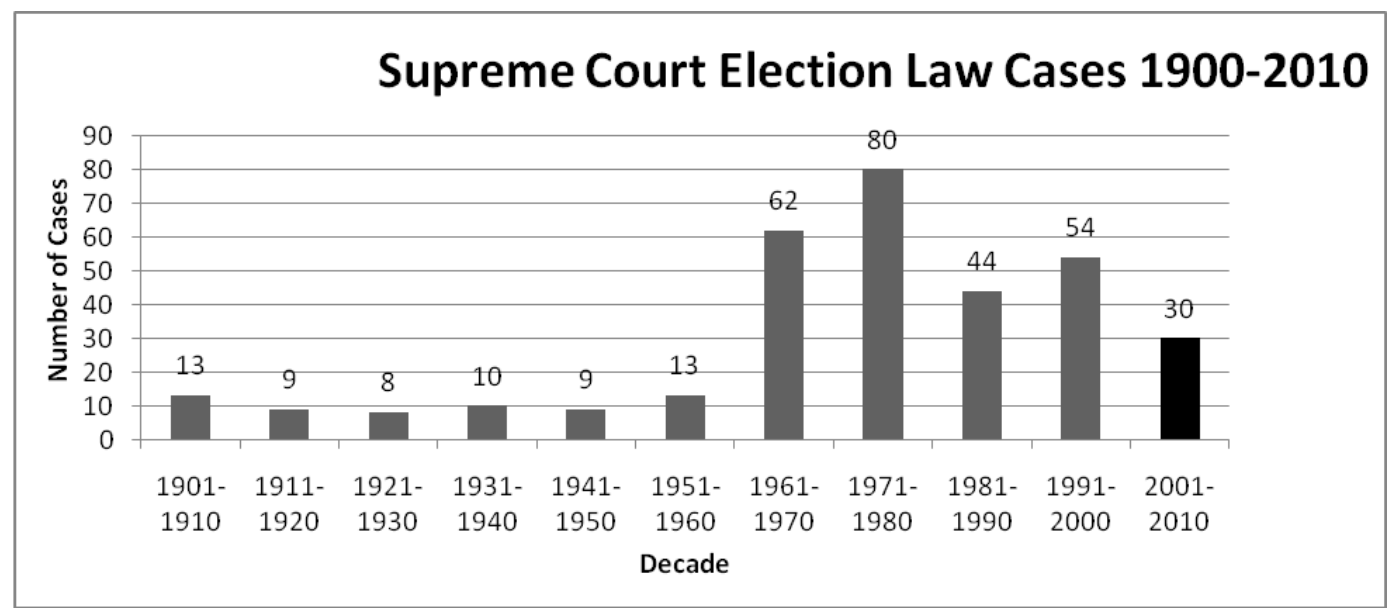

Figure 1 Sources: Hasen, supra note 3; Appendix to this Note
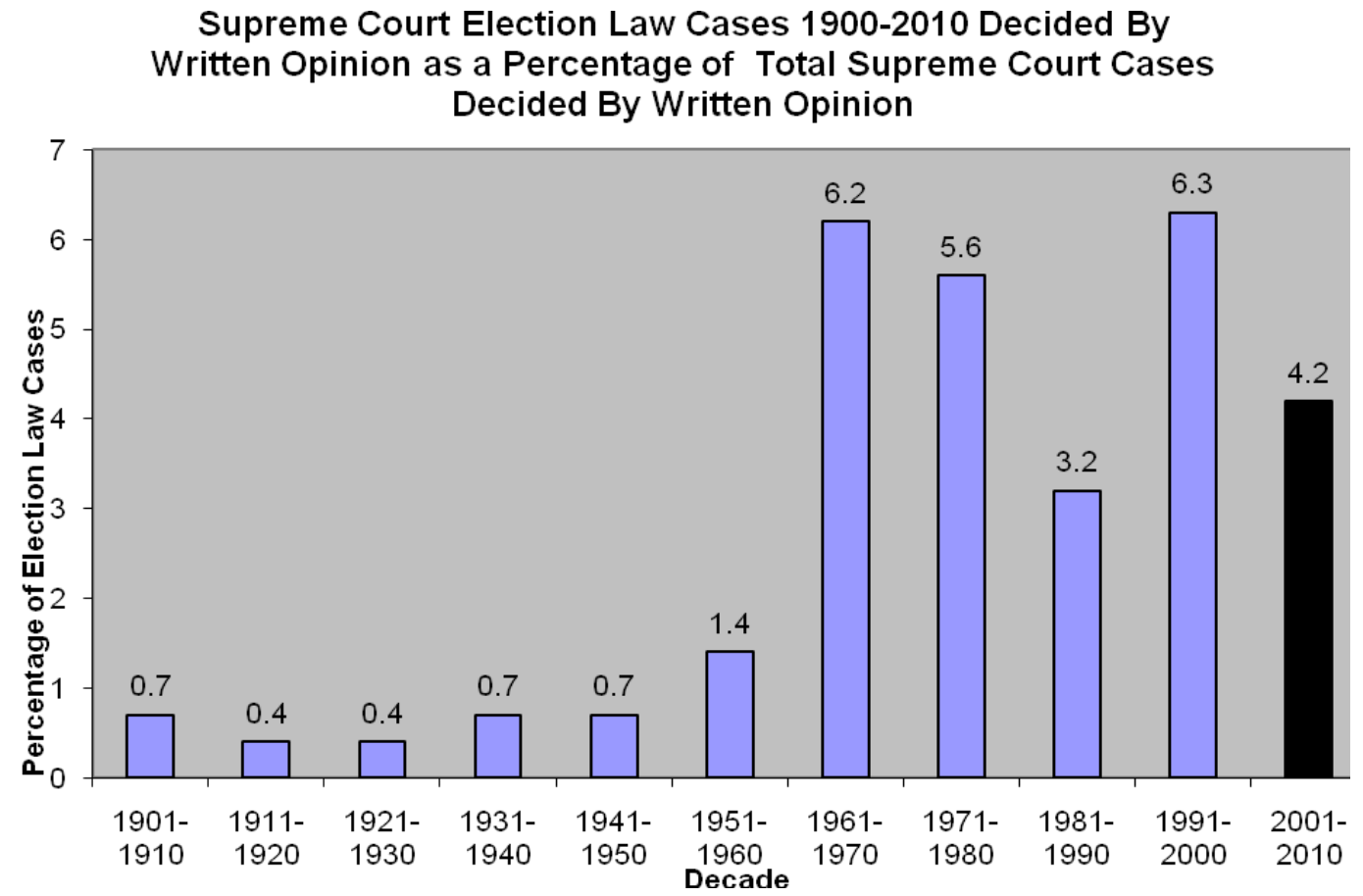

Figure 2. Source: Hasen, supra note 3; author's calculations

${ }^{7}$ The Court decided 712 cases with a written opinion from January 1, 2001 to December 31, 2010. I list the 30 election law cases decided by the Court in the 2001-2010 period in the Appendix to this Article. 
One would have to go back to the pre-Baker 1951-1960 decade to find a decade with a smaller number of election law cases decided by the Supreme Court. $^{8}$ Comparing the most recent decade to the decade before that one, the Court's docket saw a $44 \%$ decrease in the number of election law cases decided, and a one-third decrease in election law cases as a percentage of the Supreme Court's docket.

These statistics would be interesting enough if the amount of election law litigation in the lower courts remained static. However, it did not do so. The period after Bush v. Gore witnessed an explosion in the amount of lower court election law litigation. In the pre-2000 period, state and federal courts handled an average of about 94 election cases per year. From 2001-2010, that number more than doubled to an average of 239 election cases per year. ${ }^{9}$ See Figure 3 . Thus, the Court saw a plunge in the number of election law cases decided just as the total amount of election law litigation in lower courts witnessed a dramatic rise.

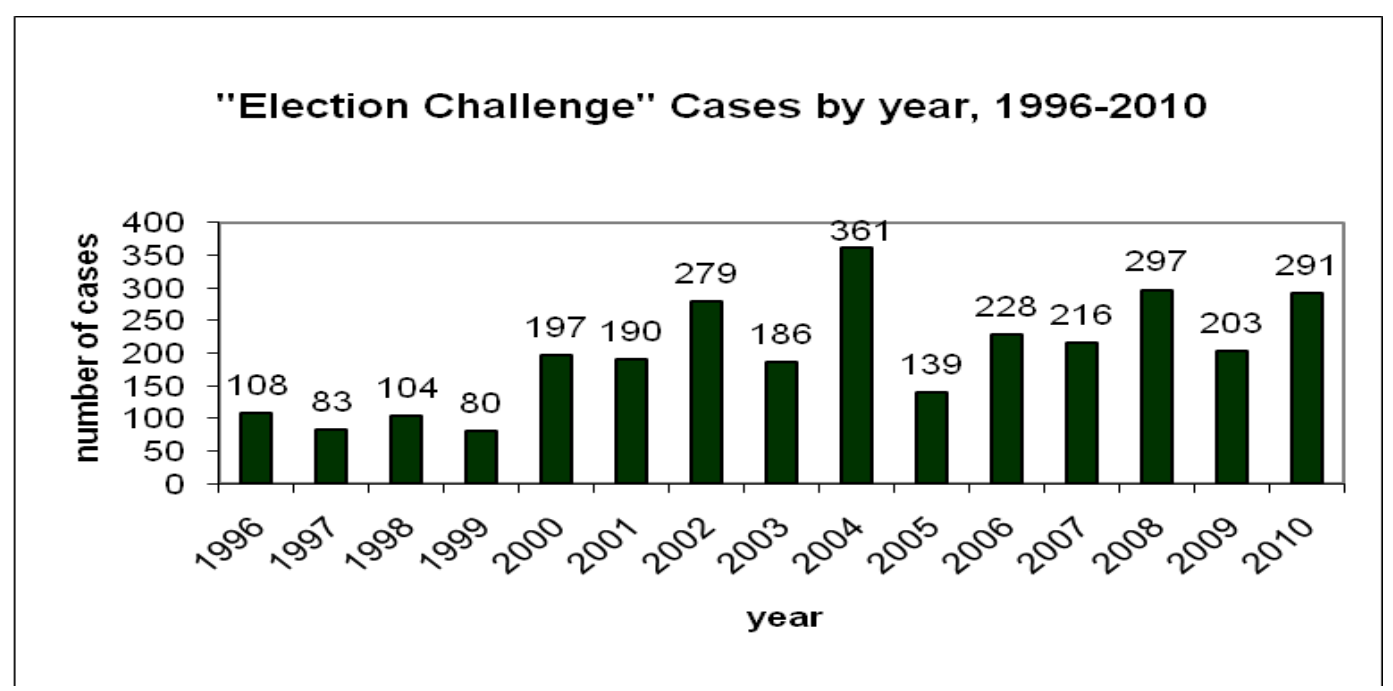

Figure 3.

${ }^{8}$ The numbers are less dramatic considering the percentage of election law cases in the total Supreme Court docket. One would have to go back only to 1981-1990 to find a decade with a smaller percentage $(3.2 \%)$ of the Court's total docket. In that decade however, the Court decided 1,387 cases, almost double the 712 cases decided in 2001-2010.

${ }^{9}$ Richard L. Hasen, The Democracy Canon, 62 STAN. L. REV. 69, 90 (2009) describes the data through 2008. For data and cases for the 2009-10 period, see http://electionlawblog.org/archives/2009-2010\%20Election\%20Litigation\%20Cases.xlsx. 


\section{POSSIBLE EXPLANATIONS}

Why did the Supreme Court's docket see a dramatic decline in the number of written election law opinions the post-2000 period? Here I consider four possible explanations based upon: (1) the nature of the Court's election law cases; (2) the number of petitions in which litigants sought Supreme Court review in election law cases; (3) Bush v. Gore fatigue; and (4) random noise.

\section{A. $\quad$ The Nature of Supreme Court Cases}

One possible reason for a decline in a class of cases decided by the Supreme Court in a written opinion would be if earlier Court opinions (or congressional action) cut off further issues for Supreme Court review. For example, if the Court decided that reapportionment cases were again nonjusticiable (as such cases were before 1962), then it would make sense that the number of such cases would go down.

There is little in recent Supreme Court election law cases signaling the closing of the courthouse door in election law cases. If anything, the Court's recent election law cases (including Bush v. Gore's uncertain equal protection holding) have left the Court door open to new claims by creating new uncertainty in numerous election law areas.

Specifically, the Court has thus far rejected partisan gerrymandering claims (Veith, $L U L A C^{10}$ ), but it (through Justice Kennedy, the deciding vote) has deliberately kept the door open for litigants to advance new arguments to demonstrate that particular partisan gerrymanders are unconstitutional. The Court has created new uncertainty about the meaning of section 2 of the Voting Rights Act, seeming to merge some of the standards for section 2 violations with the standards applicable to unconstitutional racial gerrymanders (LULAC, Bartlett). It has left open the question of the constitutionality of Section 5 of the Voting Rights Act (NAMUDNO), raised new statutory questions about the meaning of Section 5 (Riley), and potentially muddied the relationship between Section 5 and unconstitutional racial gerrymandering claims (Easley). The Court has shifted its campaign finance jurisprudence wildly, going from a period of unprecedented deference to campaign finance laws (Shrink Missouri, Beaumont, McConnell) to a period of unprecedented skepticism (Citizens United, Davis, WRTL), opening up the courts to new challenges over longstanding campaign finance and related practices. It has signaled a future battle over the scope of as-applied exemptions to government laws mandating the disclosure of campaign finance and similar election information (Doe). It has also recognized that campaign spending in

\footnotetext{
${ }^{10}$ The full citations to the cases cited in this paragraph appear in the Appendix.
} 
judicial elections may create due process problems that require judicial recusal, but it did not provide firm guidelines about when due process requires recusal (Caperton). The Court has upheld the use of voter identification laws under some circumstances (Purcell), but it set forth a constitutional test through a two threeJustice plurality opinions leaving great uncertainty in the scope of the law (Crawford). ${ }^{11}$ The Court decided its most recent case raising First Amendment associational rights questions about a state's political primary rules as an asapplied challenge, leaving the door open to future, fact-specific challenges related to the specific nature of each state's primary system (Washington State Grange).

In short, while there is much to say about the Court's election law jurisprudence from the last decade, it would not seem fair to characterize the jurisprudence as closing off areas for further Supreme Court review.

\section{B. Decline in Supreme Court Election Law Cases in Which Litigants Sought Review}

A more fruitful line of inquiry examines the number of cases in which parties sought Supreme Court review. If fewer litigants were asking for the Supreme Court to review their election law cases, that decline could help explain why the Court could decide to take fewer cases.

To examine whether there was a decline in the number of cases in which litigants sought review, I considered petitions for writs of certiorari and jurisdictional statements in direct appeals ${ }^{12}$ listed in BNA's U.S. Law Week annual subject index under "Elections" or "Apportionment" from January 1,

${ }^{11}$ Christopher S. Elmendorf \& Edward B. Foley, Gatekeeping vs. Balancing in the Constitutional Law of Elections: Methodological Uncertainty on the High Court, 17 WM. \& MARY BILL OF RTS. J. 507 (2008).

${ }^{12}$ By statute, certain redistricting, voting rights, and campaign finance cases come up to the Supreme Court on direct appeal from a three-judge court rather than through a discretionary petition for writ of certiorari. For background on the direct appeal process see Joshua A. Douglas, The Procedure of Election Law in Federal Courts, 2011 UTAH L. REV. (forthcoming 2011), draft available at: http://papers.ssrn.com/sol3/papers.cfm?abstract_id=1679518; Michael E. Solimine, The Three-Judge District Court in Voting Rights Litigation, 30 U. Mich. J.L. REFORM 79, 132 (1996). About half the cases the Court decided from 2001 to 2010 came to the Court on direct appeal rather than through a petition for certiorari. As I explain in Hasen, supra note 3, discussing the Court's treatment of the famous poll tax case, Harper v. Virginia Board of Elections, 383 U.S. 663 (1966), the Court is more likely to take cases coming to it on direct appeal. Unlike with denial of a petition for writ of certiorari, a summary affirmance of a lower court decision has actual, though limited, precedential value. Illinois State Bd of Elections v. Socialist Workers Party, 440 U.S. 173, 182-83 (1979); see also Michael E. Solimine, Institutional Process, Agenda Setting, and the Development of Election Law on the Supreme Court, 68 OHIO ST. L.J. 767, 796-99 (2007) (discussing direct review by the Supreme Court in recent election law cases).

${ }^{13}$ I excluded non-election law cases listed under apportionment, and counted each case only once per term. A handful of cases were listed in multiple years as cases were held over from one term to 
1991 in the 1990-91 term through the October 2010 term (including decisions made no later than December 31, 2010). For 1991-2000, BNA lists 454 election law petitions. In that period the Court issued 54 written opinions in election law cases, a written opinion rate of 11.9 percent. For 2001-2010, BNA lists 287 election law petitions. In the latter period the Court issued 30 written opinions in election law cases, a written opinion rate of 10.5 percent. Comparing the decades, the number of election law petitions considered by the Court dropped by over 36 percent from one decade to the next.

Thus, the Court agreed to consider and write opinions in close to the same percentage of election law cases in which litigants filed petitions in the last two decades. A dramatically different input (the universe of election law cases that the Court could agree to hear and issue a written opinion) led to a proportionally similar output (the number of Supreme Court election law written opinions). Figure 4, appearing and discussed in Part III, shows the number of election law petitions by year over the last 20 years.

\section{Bush v. Gore Fatigue?}

Though it appears that the main reason for the decline in written election law opinions by the Supreme Court is the lower number of petitions seeking review in the 2001-2010 period, I cannot eliminate two other possibilities. The first is Bush v. Gore fatigue.

Is it possible that the Court has become gun-shy about deciding election law cases following the reactions on and off the Court to the controversial decision? There certainly is some evidence that the Court has tried to avoid controversy surrounding Bush v. Gore itself. Since the case was decided, no Court opinion-majority, plurality, concurrence, or dissent-has cited or even mentioned the case. ${ }^{14}$ This is so even though it would have been natural to cite the

the next, but the dispersion of these cases seemed to be random, and I did not go through and remove these cases from my count. For years at the edges of my study count-1991, 2000, and 2010 - I counted petitions in which the Court had made a final decision (to deny a petition for certiorari, dismiss or affirm a direct appeal, or decide a granted case on the merits) on that petition in that calendar year. Finally, my count for cases in the latter part of the 2010 period came not from the annual subject index (which was not yet available for the October 2010 term), but from an electronic index from BNA which lists all petitions.

${ }^{14}$ Chad Flanders, Please Don't Cite This Case! The Precedential Value of Bush v. Gore, 116 YALE L.J. POCKET PART 141, 144 (2006), http://thepocketpart.org/2006/11/07/flanders.html (noting that the Supreme Court had not cited Bush v. Gore for any proposition). As of March 2011, the only almost-exception is Chief Justice Roberts' concurring opinion in Citizens United $v$. Federal Election Commission, in which the Chief Justice cited my book which has the words "Bush v. Gore" in the title. 
case in certain opinions. ${ }^{15}$ It is quite rare to find a Supreme Court case (at least a few years old) aside from Bush v. Gore that has not been cited at least once by some Justice at least for some anodyne proposition. ${ }^{16}$

Whether the Court's reticence in relation to Bush v. Gore translates into a general reluctance to hear election law cases is a plausible conjecture, but there is no way that the conjecture could be proven short of an admission from Supreme Court Justices about an internal practice to avoid such cases. (Even asking for an admission would not work if Bush v. Gore has led to a subconscious reluctance to decide such cases.) Certainly in considering the election law cases that the Court did decide from 2001-2010, the Court has not shied away from controversy. Citizens United, for example, is probably the most prominent and controversial Supreme Court case in any subject area since Bush v. Gore. The Court also considered the constitutionality of controversial voter identification provisions from Indiana (Crawford) and a lawsuit over the Tom DeLay-inspired Texas reredistricting.(LULAC). If the Court in the last decade had been trying to avoid controversy in election law cases, it did not do a very good job.

If the conjecture that Bush v. Gore made the Court gun-shy is correct, the Court should become more willing to hear election law cases going forward, as the controversy over Bush v. Gore fades with time. This suggests that, all else being equal, we should see an uptick in the number of election law cases heard from 2011-2020, even if the number of election law petitions seeking review remains constant.

\section{The Decline as Random Noise?}

Though the Bush v. Gore hypothesis is plausible, it is also plausible that part of the decline in election law cases in the last decade is nothing more than random noise. Looking across the decades, there is considerable variation in the number of election law cases decided per decade. For example, without detailed examination of the petitions considered, ${ }^{17}$ it is hard to explain the precipitous drop in the number of election law cases decided with a written opinion from the 80 cases in the 1971-1980 period to the 44 cases in the 1981-1990 period.

\footnotetext{
15 See Richard L. Hasen, When "Legislature" May Mean More than "Legislature:" Initiated Electoral College Reform and the Ghost of Bush v. Gore, 35 HASTINGS CONST. L.Q. 599, 618-19 (2008) (discussing the failure of Chief Justice Rehnquist to discuss his Bush v. Gore concurrence in his dissent from denial of a certiorari petition in a case raising almost an identical issue).

${ }^{16}$ After a long search, I found another rare exception, Ohler v. U.S., 529 U.S. 753 (2000). As of March 2011, Ohler, like Bush v. Gore, had not been cited by the Supreme Court for any proposition,

17 One possibility: the earlier period marked the beginning of the Court's sustained effort to interpret the Voting Rights Act and federal, state and local campaign finance laws.
} 
Part of the decline in the 2001-2010 decade might be due to the opportunity cost of hearing election law cases. The Court hears only a small percentage of cases in which litigants sought review. It might be that the Supreme Court had more compelling cases to review in the 2001-2010 period aside from election law cases. The last decade at the Supreme Court saw important decisions related to the scope of federal power, the war on terror, Second Amendment gun rights, gay rights, federal sentencing, and the scope of constitutional criminal procedure protections. Some election law disputes simply may have been less compelling for a Court that has seen fit to shrink its overall docket dramatically overall in the last two decades. If this explanation is correct, it is hard to predict whether we would see some uptick in the number of election law cases being decided in the current decade, closer to the historic post-1960 rates of cases. It depends upon the nature of the other petitions filed in the Court.

\section{EXPLAINING THE DECLINE IN ELECTION LAW Litigants SEEKING SuPREME COURT REVIEW}

The last section posits that the most plausible explanation for the decline in election law cases heard by the Court the last decade was a decline in the number of petitions seeking review in election law cases. Why did the Court's docket see a dramatic decline in the number of election law cases in which litigants sought Supreme Court review? Here, I suggest two possibilities. First, my earlier research has shown that much of the post-Bush v. Gore increase in election law litigation in the lower courts involved statutory interpretation questions under state law. ${ }^{18}$ These cases typically would not be good candidates for U.S. Supreme Court review, because the Court reviews only constitutional and federal statutory questions, not state law questions (except in the rare case in which the state law interpretation itself raises a constitutional question, as in Bush v. Gore).

Second, there is some evidence that liberal litigants are more wary of filing petitions in election law cases before the more conservative Roberts Court. ${ }^{19}$

${ }^{18}$ See Hasen, supra note 9.

${ }^{19}$ See Richard L. Hasen, How Liberals Can Win by Losing at the Roberts Court, SLATE, Sept. 14, 2009, available at: http://www.slate.com/id/2228257/. On the general question of litigant strategy before the Supreme Court and how that shape's the Court's docket, see VANESSA BAIRD, Answering the CAll of THE Court: How Justices and Litigants SET the Supreme Court AGENDA 4 (2007) ("The main argument [in this book] is that the incentive to support litigation in particular policy areas varies over time in accordance with litigants' changing perceptions of Supreme Court justices' policy priorities"). Another possibility, which I do not explore here, is that incentives related to attorneys fees in civil rights cases have led to a decline in the number of cases that make it to final judgment, and therefore the number of cases in which Supreme Court 
Figure 4, which charts the election law petitions filed in the Supreme Court each year in the last two decades shows what appears to be a precipitous drop around the time that Justice Alito replaced Justice O'Connor in the mid-2000s. For example, a litigant seeking to expand the scope of the Voting Rights Act would be foolish to try to do so before the current Supreme Court, where a majority seems skeptical of both the Act's reach and its constitutionality. It might be better for a litigant to live with a decision she dislikes from a lower court than to have a similar (or worse) decision nationalized by a Supreme Court ruling.

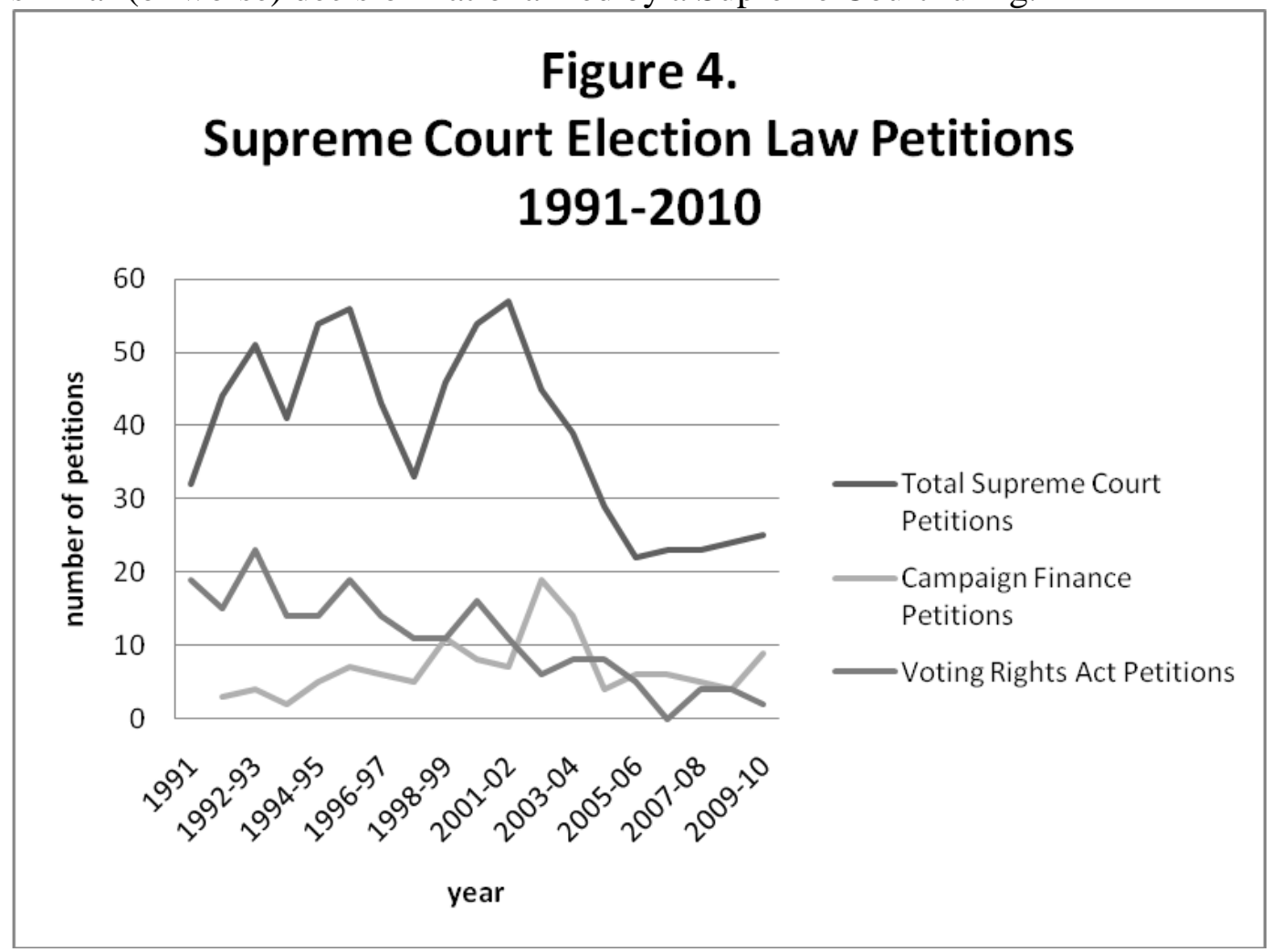

Some evidence that litigants are responding to changes in the political valence of the Court comes if we break out two classes of election law petitions: campaign finance cases and cases raising issues under the Voting Rights Act. ${ }^{20}$ The Voting Rights Act cases, many of which were filed by plaintiffs seeking

review is possible. See Buckhannon Board \& Care Home, Inc. v. West Virginia Dep't of Health \& Human Servs., 532 U.S. 598 (2001). But Buckhannon, a 2001 case, cannot explain the precipitous drop in petitions after 2005.

${ }^{20}$ For these figures, I counted cases listed in the BNA subject index for "Elections" primarily under "campaign finance regulation" and "Voting Rights Act." But I also counted other cases as well when the description appeared to consider these issues (as with racial gerrymandering cases). 
expansion of the Act, show a general decline from the 1990s forward, with only a handful of cases being filed in the most recent Roberts Court period. ${ }^{21}$ The campaign finance cases are more volatile, with an unsurprising peak soon after Congress passed the Bipartisan Campaign Reform Act of 2002 ("McCainFeingold"). The last few years show an uptick, which corresponds to the period in which the Roberts Court has struck down or limited every campaign finance case it has considered thus far. ${ }^{22}$ Most of the recent campaign finance petitions filed in the Supreme Court challenge the constitutionality of campaign finance laws upheld by lower courts. There are few cases in which a lower court has struck down a campaign finance law and a government or campaign finance reform group seeks to get the Supreme Court to reverse a finding of unconstitutionality.

\section{CONCLUSION}

The shrinking of the Supreme Court's election law docket in the last decade is noteworthy. While it does not appear to mark a retreat from the political thicket, it does show that the Court's willingness to provide guidance on the scope of the constitutional and statutory rules of the political process ebbs and flows over time. It is easy to casually attribute the decline to a Supreme Court's recoil from the reaction to the controversial Bush v. Gore decision. But correlation does not prove causation. It seems more plausible that the main cause of the decline was a decrease in the number of petitions seeking Supreme Court review in more recent years, which could itself be the product of the rise of a more conservative Supreme Court as Justice Alito replaced Justice O'Connor. If that's the case, the number of election law cases heard by the Supreme Court should remain low, unless conservative litigants bring more suits to reverse or cabin earlier, more liberal election law precedents.

\section{APPENDIX: SuPREME COURT ELECTION LAW CASES DECIDED BY A WRITTEN OPINION, 2001-2010}

1. Cook v. Gralike, 531 U.S. 510 (2001)

2. Easley v. Cromartie, 532 U.S. 234 (2001)

3. FEC v. Colorado Republican Federal Campaign Committee, 533 U.S. 431 (2001)

\footnotetext{
${ }^{21}$ I would expect some uptick in the next few years, as Voting Rights Act cases arising out of the new round of redistricting work their way through the courts to the Supreme Court.

${ }^{22}$ The cases are: Randall v. Sorrell, Wisconsin Right to Life v. FEC, Davis v. FEC, and Citizens United.
} 
4. Utah v. Evans, 536 U.S. 452 (2002)

5. Republican Party of Minnesota v. White, 536 U.S. 765 (2002)

6. Branch v. Smith, 538 U.S. 254 (2003)

7. FEC v. Beaumont, 539 U.S. 146 (2003)

8. Georgia v. Ashcroft, 539 U.S. 461 (2003)

9. McConnell v. FEC, 540 U.S. 93 (2003)

10. Vieth v. Jubelirer, 541 U.S. 267 (2004)

11. Clingman v. Beaver, 544 U.S. 581 (2005)

12. Wisconsin Right to Life, Inc. v. FEC, 546 U.S. 410 (2006)

13. Lance v. Dennis, 546 U.S. 459 (2006)

14. Randall v. Sorrell, 548 U.S. 230 (2006)

15. League of United Latin American Citizens v. Perry, 548 U.S. 399 (2006)

16. Purcell v. Gonzalez, 549 U.S. 1 (2006)

17. Lance v. Coffman, 549 U.S. 437 (2007)

18. FEC v. Wisconsin Right to Life, Inc., 551 U.S. 449 (2007)

19. New York State Board of Elections v. Lopez Torres, 552 U.S. 196 (2008)

20. Washington State Grange v. Washington State Republican Party, 552 U.S. 442 (2008)

21. Crawford v. Marion County Election Board, 553 U.S. 181 (2008)

22. Riley v. Kennedy, 553 U.S. 406 (2008)

23. Davis v. FEC, 128 S. Ct. 2759 (2008)

24. Brunner v. Ohio Republican Party, 129 S. Ct. 5 (2008)

25. Ysursa v. Pocatello Education Association, 129 S. Ct. 1093 (2009)

26. Bartlett v. Strickland, 129 S. Ct. 1231 (2009)

27. Caperton v. Massey, 129 S. Ct. 2252 (2009)

28. NAMUDNO v. Holder, 129 S. Ct. 2504 (2009)

29. Citizens United v. FEC, 130 S. Ct. 876 (2010)

30. Doe v. Reed, 130 S. Ct. 2811 (2010) 